\title{
VERTICAL PRODUCTION OF 'KONSTANCIN' ROSE CUTTINGS IN THE GROWTH CHAMBER UNDER LED LIGHT
}

\author{
Short communication \\ Bożena MATYSIAK* \\ Research Institute of Horticulture \\ Konstytucji 3 Maja 1/3 St., 96-100 Skierniewice, Poland \\ Received: May 2020; Accepted: September 2020
}

\begin{abstract}
The impact of light quality generated by light-emitting diodes (LEDs) on the adventitious root formation and cuttings' quality of rose hip 'Konstancin' under controlled conditions in multilevel growth chamber without access to natural light and in the greenhouse was evaluated. In the growth chamber, the lighting was provided by a combination of red and blue LED arrays and white LED tubes, while in the greenhouse, red and blue LED lights were used as a supplement to natural light. The number of rooted cuttings under both growth conditions was not affected by the light conditions generated by LEDs. However, light quality showed significant effects on the biomass production and development of adventitious roots, with the most stimulating red light generated by LEDs. In the growth chamber, the root biomass of the cuttings illuminated with white LEDs supplemented with red LEDs was on average 2.2 times higher than of the cuttings illuminated with white LEDs only. A similar reaction was noted under greenhouse conditions. Supplementation of natural light with red LEDs resulted in 1.7 times increase of the fresh biomass of roots. Both in the growth chamber and in the greenhouse, illumination with red LEDs promoted axillary bud outgrowth. LED lamps can be used in the production of high-quality rose cuttings, both in greenhouses as a complement to natural light and in multilevel rooms as a sole-source lighting for plants.
\end{abstract}

Key words: Rosa, hip rose, light spectrum, root quality, vegetative propagation

\section{INTRODUCTION}

Rose hips are a rich source of bioactive compounds with potential beneficial effects on human health. There is growing demand for good quality and uniform planting materials for establishing rose hip plantation. The low rooting ability of stem cuttings of many selected genotypes of hip roses and heterogeneousness of generative planting material are the limiting factors for rapid implementation of rose hip in horticultural production.

There is great variation in the rooting capacity of cuttings of fruit-producing rose genotypes. Depending on the time of harvesting the cuttings and the type and concentration of phytohormones used, the percentage of cutting rooting varies from $10 \%$ to $86 \%$ for selected Rosa canina clones (Ercişli \& Güleryüz 1999, Ercişli et al. 2005, Hoşafçı et al. 2005, Kazankaya et al. 2005). In case of Rosa foetida, it was only 3\% (Ercişli \& Güleryüz 1999) and for Rosa dumalis and Rosa pomifera 'Karpatia', it did not exceed 70\% (Ercisli et al. 2004, Ercişli et al. 2005). Rosa 'Konstancin' (an interspecific hybrid between Rosa rugosa and Rosa beggeriana), which was selected in 1972 in the Forest Research Institute in Warsaw (Poland), is characterized by extremely high amount of L-ascorbic acid, i.e. $-2150-3500 \mathrm{mg}$ in $100 \mathrm{~g}$ of fresh matter (Milewski 1974, Matysiak et al. 2019). 
Thus, there is a high demand from the food industry and pharmacy for those fruits, but currently there is no effective vegetative propagation method available for this cultivar. In the previous study, we had developed an efficient in vitro propagation protocol for Rosa 'Konstancin' (Wojtania \& Matysiak 2018), which can be used for the production of high-quality stock mother plants.

Light is an important factor for modulating root development, and providing optimal light conditions can greatly improve the success of propagation. Light-emitting diodes (LEDs) have many potential benefits for propagation. The narrow emission spectra of LEDs allow to design a lighting system capable of stimulating specific photoreceptors (Davis \& Burns 2016). Using spectral manipulation to improve propagation efficiency is of particular interest for high-value crops that are difficult to root. Many scientific reports concern the impact of light quality on plant reproduction using micropropagation techniques (Miler et al. 2019), and little work is related to ornamental plant propagation by softwood cuttings (Christiaens et al. 2016). It has been demonstrated that limiting the spectrum to $100 \%$ red light is not always optimal for propagation, but a range of red to blue light mixtures have been found to produce optimal rooting conditions for several species (Christiaens et al. 2016, Davis \& Burns 2016). However, there is not much information available on the potential benefits of LED lighting for rooting cuttings of woody plants, including Rosa spp.

Vertical farming is the production of plants in multiple vertical layers indoors with a controlled environment and LEDs as the only light source (Kozai et al. 2020). In the past few years, there has been a worldwide increase of interest in vertical farming, especially to produce high-value specialty crops including leafy greens, herbs, and pharmaceutical crops. Indoor vertical production may also have many potential benefits for growing crops that are difficult to propagate in less-controlled greenhouse environments.

The aim of the study was to assess the impact of light quality generated by LEDs on adventitious root formation and cuttings' quality of Rosa 'Konstancin' in controlled conditions in the multilevel growth chamber without access to natural light and in the greenhouse.

\section{MATERIALS AND METHODS}

Two-node softwood cuttings, 4-5 cm long, of Rosa 'Konstancin' ( $R$. rugosa $\times R$. beggeriana) were collected from container-greenhouse-grown stock plants ( 1 year old, reproduced in vitro). All cuttings were inserted to a depth of $1-1.5 \mathrm{~cm}$ into a mixture of peat moss and perlite $(3: 1 \mathrm{v} / \mathrm{v}, \mathrm{pH} 5.6-6.4)$ in plastic boxes $(40 \times 60 \times 7 \mathrm{~cm})$ with a transparent cover $(15 \mathrm{~cm}$ high) with adjustable vents. There were 30 cuttings in each box. No growth regulators were used to stimulate adventitious root formation. The substrate was watered in advance of inserting cuttings. All cuttings were evaluated for rooting percentage, number of roots per cutting, root length, fresh weight of roots, number of cuttings with new shoots, shoot length, and fresh weight of shoot at the end of their respective rooting period. Two experiments were carried out: one in a growth chamber and one in a climate-controlled greenhouse.

\section{Experiment 1}

The experiment was conducted in a $15-\mathrm{m}^{2}$ walk-in growth chamber equipped with three levels of shelves on both sides with white LED tubes $(6500 \mathrm{~K})$ mounted above the shelves. Four different light treatments (16/8-h light/dark photoperiod) were applied during the rooting period as follows: 1) white LED tubes at $50 \mu \mathrm{mol} \cdot \mathrm{m}^{-2} \cdot \mathrm{s}^{-1}$ (control), 2) white LED tubes at $\left.100 \mu \mathrm{mol} \cdot \mathrm{m}^{-2} \cdot \mathrm{s}^{-1}, 3\right) \mathrm{red}$ LEDs at $50 \mu \mathrm{mol} \cdot \mathrm{m}^{-2} \cdot \mathrm{s}^{-1}+$ white LED tubes at $50 \mu \mathrm{mol} \cdot \mathrm{m}^{-2} \cdot \mathrm{s}^{-1}$, and 4) blue LEDs at $50 \mu \mathrm{mol} \cdot \mathrm{m}^{-2} \cdot \mathrm{s}^{-1}+$ white LED tubes at $50 \mu \mathrm{mol} \cdot \mathrm{m}^{-2} \cdot \mathrm{s}^{-1}$. Slim panels ( $130 \mathrm{~cm}$ in length) of custom-built LED arrays containing red $(660 \mathrm{~nm})$ or blue $(440 \mathrm{~nm})$ LEDs (OSRAM, Germany) were arranged between white LED tubes to ensure adequate light quality for treatments 3 and 4 . To obtain an adequate photosynthetic photon flux density (PPFD) value, various numbers of white LED tubes (three or five) were used per shelf, and also the distance between the light source and the shelves was adjusted. PPFD was measured in the middle part of empty shelves without plants, separately for white LED tubes and red or blue LED lights. PPFD was measured using a LI-COR quantum photometer Model LI-189. The spectrum of light emitted by white LED tubes, white LED tubes + red LEDs, and white LED tubes + blue LEDs is shown in Figure 1. 

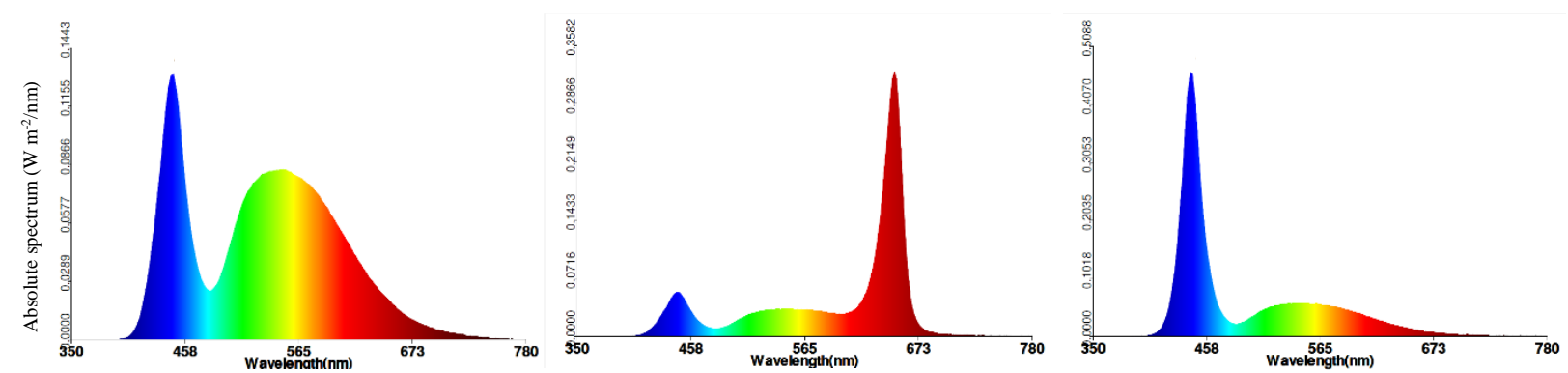

Fig. 1. Spectra of different light treatments used in the study: white LED tubes (left), white LED tubes + red LEDs (middle), and white LED tubes + blue LEDs (right), absolute spectrum ( $\left.\mathrm{W} \mathrm{m}^{-2} / \mathrm{nm}\right)$

The emission spectra were measured with LI-180 spectrometer (LI-COR). The shelves with different light treatments were separated with white, lightproof screens. The daily light integrals (DLIs) were $2.88 \mathrm{~mol} \cdot \mathrm{m}^{-2} \cdot \mathrm{d}^{-1}$ for control and $5.76 \mathrm{~mol} \cdot \mathrm{m}^{-2} \cdot \mathrm{d}^{-1}$ for other treatments. Temperature in the growth chamber was automatically regulated at $21^{\circ} \mathrm{C}$. Four boxes with cuttings were placed per shelf $(60 \times 130 \mathrm{~cm})$. Cuttings were prepared on July 19, 2018 and evaluated after 5 weeks (23 August). One hundred and twenty cuttings per treatment (four boxes) were subjected to each light treatment.

\section{Experiment 2}

The second part of the study was carried out in a greenhouse chamber $(5 \times 4 \mathrm{~m})$ equipped with four ebb and flow benches. Four different light treatments were applied during the rooting period (i.e. - from 17 September to 22 October 2019) as follows: 1) control, natural light; 2) natural light supplemented with white LEDs; 3) natural light supplemented with red LEDs; and 4) natural light supplemented with blue LEDs. The natural photoperiod throughout the experimental time was on average $11.5 \mathrm{~h}$ (initially $12.5 \mathrm{~h}$ and at the end of experiment $10.5 \mathrm{~h}$ ), and the average DLI inside the greenhouse was $5.18 \mathrm{~mol} \cdot \mathrm{m}^{-2} \cdot \mathrm{s}^{-1}$. Slim, $120-\mathrm{cm}$ long, custom-built LED arrays containing red $(660 \mathrm{~nm})$ or blue $(440 \mathrm{~nm})$ diodes, such as in the first experiment, and white LEDs (cool-white $5000 \mathrm{~K}$, OSRAM, Germany) were mounted above the benches. Four panels were used above each bench. LED lighting was used as a supplementary to greenhouse light when dusk began $(6 \mathrm{p} . \mathrm{m}$. to $10 \mathrm{p}$.m.) at PPFD $120 \mu \mathrm{mol} \cdot \mathrm{m}^{-2} \cdot \mathrm{s}^{-1}$ at the plant level; thus, DLI inside the greenhouse was increased by $1.73 \mathrm{~mol} \cdot \mathrm{m}^{-2} \cdot \mathrm{d}^{-1}$. Four boxes of 30 cuttings were placed under each light treatment. Daily maximum/minimum temperature was $21^{\circ} \mathrm{C} \pm 3{ }^{\circ} \mathrm{C} / 18^{\circ} \mathrm{C} \pm 3{ }^{\circ} \mathrm{C}$.

\section{Statistical analysis}

The experiment design included four light treatments with four replications for both experiments.
One box consisting of 30 cuttings was treated as one replication. Treatments were analyzed by one-way analysis of variance (ANOVA); means were compared using Tukey's tests at $p=0.05$. The data concerning the percentage of rooted cuttings were formerly transformed according to Bliss' function.

\section{RESULTS AND DISCUSSION}

Percentage of rooted cuttings of Rosa 'Konstancin' was very high in the growth chamber (8393\%) under LEDs as the only light source and 16-h photoperiod (Table 1) and lower in the greenhouse (62-68\%) when LED light extended the exposure time of 12-h sunlight by $4 \mathrm{~h}$ (Table 2). The number of rooted cuttings under both growth conditions was not affected by the light quality generated by LEDs. However, this factor showed significant effects on the biomass production and development of adventitious roots, with the most stimulating red light generated by LEDs. In the growth chamber, the root biomass of the cuttings illuminated with white LEDs supplemented with red LEDs was on average 2.2 times higher than of the cuttings illuminated with white LEDs only, both at lower $\left(50 \mu \mathrm{mol} \cdot \mathrm{m}^{-2} \cdot \mathrm{s}^{-1}\right)$ and higher $\left(100 \mu \mathrm{mol} \cdot \mathrm{m}^{-2} \cdot \mathrm{s}^{-1}\right)$ PPFD. A similar reaction was noted under greenhouse conditions. Under natural light supplemented with red LEDs, the fresh biomass was 1.7 times higher than under natural light conditions and the roots were the longest. Blue light used as a supplement to natural light performed as a poorer light source to induce adventitious roots of Rosa 'Konstancin' both in the growth chamber and in the greenhouse. Similarly, white LEDs, used in the growth chamber at 50 or $100 \mu \mathrm{mol} \cdot \mathrm{m}^{-2} \cdot \mathrm{s}^{-1}$ as the sole light source or for extending the day at $120 \mu \mathrm{mol} \cdot \mathrm{m}^{-2} \cdot \mathrm{s}^{-1}$ in the greenhouse, did not affect the rooting percentage and the number of roots per cutting. 
Table 1. Rooting and initial growth of shoots on two-node cuttings of Rosa 'Konstancin' in response to the quality of LED light and the intensity of irradiation in the growth chamber

\begin{tabular}{lccccccc}
\hline $\begin{array}{l}\text { LED light treatment } \\
\text { PPFD }\left(\mu \mathrm{mol} \cdot \mathrm{m}^{-2} \cdot \mathrm{s}^{-1}\right)\end{array}$ & $\begin{array}{c}\text { Rooting } \\
(\%)\end{array}$ & $\begin{array}{c}\text { Number } \\
\text { of roots } \\
\text { per cutting }\end{array}$ & $\begin{array}{c}\text { Root } \\
\text { length } \\
(\mathrm{mm})\end{array}$ & $\begin{array}{c}\text { Fresh weight } \\
\text { of roots } \\
(\mathrm{mg})\end{array}$ & $\begin{array}{c}\text { Cuttings } \\
\text { with new } \\
\text { shoots } \\
(\%)\end{array}$ & $\begin{array}{c}\text { Shoot } \\
\text { length } \\
(\mathrm{mm})\end{array}$ & $\begin{array}{c}\text { Fresh } \\
\text { weight } \\
\text { of shoot } \\
(\mathrm{mg})\end{array}$ \\
\hline White $50-$ control & $83.3 \pm 3.6 \mathrm{a}$ & $3.3 \pm 0.41 \mathrm{a}$ & $50 \pm 0.7 \mathrm{a}$ & $79.3 \pm 17.1 \mathrm{a}$ & $26.7 \pm 3.6 \mathrm{a}$ & $15.7 \pm 3.7 \mathrm{a}$ & $274 \pm 22 \mathrm{a}$ \\
\hline White 100 & $93.3 \pm 2.4 \mathrm{a}$ & $3.9 \pm 0.57 \mathrm{a}$ & $51 \pm 3.4 \mathrm{a}$ & $89.6 \pm 15.7 \mathrm{a}$ & $43.3 \pm 7.2 \mathrm{a}$ & $25.3 \pm 3.0 \mathrm{~b}$ & $368 \pm 44 \mathrm{ab}$ \\
\hline White 50+ Red 50 & $89.7 \pm 0.8 \mathrm{a}$ & $3.2 \pm 0.48 \mathrm{a}$ & $48 \pm 4.7 \mathrm{a}$ & $183.0 \pm 27.9 \mathrm{~b}$ & $66.7 \pm 3.6 \mathrm{~b}$ & $23.2 \pm 2.6 \mathrm{~b}$ & $486 \pm 21 \mathrm{~b}$ \\
\hline White 50+ Blue 50 & $86.7 \pm 1.9 \mathrm{a}$ & $2.7 \pm 0.34 \mathrm{a}$ & $44 \pm 4.2 \mathrm{a}$ & $124.5 \pm 27.4 \mathrm{ab}$ & $39.2 \pm 6.6 \mathrm{a}$ & $22.2 \pm 2.8 \mathrm{~b}$ & $354 \pm 25 \mathrm{ab}$ \\
\hline
\end{tabular}

Means followed by the same letter do not differ significantly at $\leq 0.05$ according to Tukey's test; means \pm SE

Table 2. Rooting and initial growth of shoots on two-node cuttings of Rosa 'Konstancin' in response to the quality of LED additional lighting in the greenhouse

\begin{tabular}{lccccccc}
\hline $\begin{array}{l}\text { LED light treatment } \\
\text { PPFD }\left(\mu \mathrm{mol} \cdot \mathrm{m}^{-2} \cdot \mathrm{s}^{-1}\right)\end{array}$ & $\begin{array}{c}\text { Rooting } \\
(\%)\end{array}$ & $\begin{array}{c}\text { Number } \\
\text { of roots } \\
\text { per cutting }\end{array}$ & $\begin{array}{c}\text { Root } \\
\text { length } \\
(\mathrm{mm})\end{array}$ & $\begin{array}{c}\text { Fresh weight } \\
\text { of roots } \\
(\mathrm{mg})\end{array}$ & $\begin{array}{c}\text { Cuttings } \\
\text { with new } \\
\text { shoots } \\
(\%)\end{array}$ & $\begin{array}{c}\text { Shoot } \\
\text { length } \\
(\mathrm{mm})\end{array}$ & $\begin{array}{c}\text { Fresh } \\
\text { weight } \\
\text { of shoot } \\
(\mathrm{mg})\end{array}$ \\
\hline Natural - control & $61.7 \pm 3.2 \mathrm{a}$ & $3.6 \pm 0.35 \mathrm{a}$ & $55 \pm 3.8 \mathrm{a}$ & $51.9 \pm 5.8 \mathrm{a}$ & $21.7 \pm 2.1 \mathrm{a}$ & $5.8 \pm 0.8 \mathrm{a}$ & $86 \pm 12 \mathrm{a}$ \\
\hline White 120 & $67.5 \pm 2.8 \mathrm{a}$ & $5.0 \pm 0.45 \mathrm{a}$ & $67 \pm 5.0 \mathrm{a}$ & $63.3 \pm 9.6 \mathrm{ab}$ & $38.3 \pm 6.2 \mathrm{a}$ & $7.4 \pm 1.1 \mathrm{a}$ & $120 \pm 13 \mathrm{a}$ \\
\hline Red 120 & $61.7 \pm 6.1 \mathrm{a}$ & $4.9 \pm 0.45 \mathrm{a}$ & $72 \pm 5.0 \mathrm{a}$ & $88.7 \pm 12.2 \mathrm{~b}$ & $63.4 \pm 4.5 \mathrm{~b}$ & $8.4 \pm 1.4 \mathrm{a}$ & $100 \pm 12 \mathrm{a}$ \\
\hline Blue 120 & $65.0 \pm 4.0 \mathrm{a}$ & $4.3 \pm 0.45 \mathrm{a}$ & $65 \pm 6.1 \mathrm{a}$ & $72.3 \pm 8.3 \mathrm{ab}$ & $30.0 \pm 5.3 \mathrm{a}$ & $5.6 \pm 0.7 \mathrm{a}$ & $118 \pm 22 \mathrm{a}$ \\
\hline
\end{tabular}

Note: See table 1

Auxins play a pivotal role in adventitious roots formation. Light has been reported to regulate the endogenous level of auxins and their homeostasis and transport through the plant tissues (Halliday et al. 2009, Pacurar et al. 2014). Red light has been shown to be beneficial in promoting root development in several species propagated in vitro, including strawberry (Nhut et. al. 2003), grapes (Poudel et al. 2008), Protea cynaroides (Wu \& Lin 2012), Jatropha curcas (Daud et al. 2013), and Plectranthus scutellarioides (Cho et al. 2019). Our findings coincide with those results in that red light exposure stimulated biomass production and development of adventitious roots of Rosa 'Konstancin', although it did not increase the number of rooted cuttings. The main roots of Rosa plants treated with red light were generally thicker and more branched than those of plants exposed to other light sources. Other studies found that phytochrome, the photoreceptor for red to far-red light responses, plays a role in adventitious root formation through auxinmediated action, and also that blue light receptors interact in this process (Christiaens et al. 2019). Lowering the red to far-red ratio and decreasing the phytochrome photostationary state improved adventitious rooting of Chrysanthemum morifolium. Cuttings of Platycladus, Rhododendron, and Leucothoe had improved adventitious roots when far-red was added to red (van Dalfsen \& Slingerland 2012). However, evidences related to adventitious roots formation under blue light are somewhat contradictory. Lim and Eom (2013) reported a very rapid root formation in sweet basil stem cuttings under blue light. Similarly, Schroeter-Zakrzewska and Kleiber (2014) showed that blue LED light as well as green LED light improved the rooting of Symphyotrichum novi-belgii cuttings. On the other hand, blue light inhibited root formation in strawberry plantlets (Nhut et al. 2003) and in Plectranthus (Cho et al. 2019). Our findings confirm that blue LED light used to extend the day in the greenhouse, as well as a supplement to the white LED light in the growth chamber did not contribute to the improvement of rooting of Rosa 'Konstancin' cuttings. 
In the current study, red light strongly promoted axillary bud outgrowth of Rosa 'Konstancin' stem cuttings. In the growth chamber, the highest number of cuttings with new shoots was observed under white LEDs supplemented with red LEDs (67\%) and the lowest under white LEDs at lower PPFD (27\%), and the shoot fresh weight of new shoots exposed to white and red LEDs was the highest. Such a reaction was also noted in the greenhouse when red LEDs were used as monochromatic light for extension of daylight, where the number of cuttings that produced new shoots was on average more than two times higher (63\%) than in other light treatments (average 30\%). The current knowledge revealed the key role of cytokinins and abscisic acid (ABA) synthesis in the bud in the regulation of bud growth by light (Schneider et al. 2019). Light intensity stimulates production of cytokinins (inducer of bud outgrowth) in the nodal stem segment, and a low $\mathrm{R}$ : FR ratio stimulates the production of $\mathrm{ABA}$ (inhibitor of bud outgrowth) in the bud. This process seems to be later reinforced by an increase in auxin signaling in the stem.

Too high light intensity at the initial stage of rooting may intensify leaf water deficit resulting from increased transpiration and decrease the effectiveness of the rooting process. Such a reaction was not observed in our study under an increase in PPFD from 50 to $100 \mu \mathrm{mol} \cdot \mathrm{m}^{-2} \cdot \mathrm{s}^{-1}$, irrespective of the light spectrum generated by LEDs. Moreover, the length of new shoots of Rosa 'Konstancin' in the growth chamber was significantly higher when the cuttings were exposed to a higher than a lower light intensity. Maas and Bakx (1995) reported that length and weight of lateral shoots emerging from axillary buds of Rosa 'Mercedes' rooted cuttings strongly increased with increased irradiance and by reduced blue light content in the spectrum.

It is worthwhile to underline that the growth chamber equipped with LEDs as the sole source of lighting created more favorable conditions for the growth and development of cuttings of Rosa 'Konstancin' than the greenhouse. Although the climatic conditions in the compared facilities were not completely the same, fresh biomass of new shoots and their length in the growth chamber were on average three times higher than in the greenhouse. Our study indicates the benefits of introduction of multilevel production on the shelving unit using LED lighting for the propagation nursery. However, the responses of other fruit-producing rose genotypes should be evaluated.

\section{CONCLUSIONS}

The present study has demonstrated the ability to improve the quality of rooted cuttings of Rosa 'Konstancin' derived from plants reproduced by in vitro technique through changes in light quality during the rooting phase. Red LED light stimulates the biomass of adventitious roots as well as promotes axillary bud outgrowth. LED lamps can be used in the production of high-quality rose cuttings, both in greenhouses as a supplement to natural light and in multilevel rooms as the sole source of lighting for plants.

\section{REFERENCES}

Christiaens A., Gobin B., Van Labeke M.C. 2016. Light quality and adventitious rooting: a mini-review. Acta Horticulturae 1134: 385-393. DOI: 10.17660/actahortic.2016.1134.50.

Christiaens A., Gobin B., Van Huylenbroeck J., Van Labeke M.C. 2019. Adventitious rooting of Chrysanthemum is stimulated by low red:far-red ratio. Journal of Plant Physiology 236: 117-123. DOI: 10.1016/j.jplph.2019.03.008.

Cho K.H., Laux V.Y., Wallace-Springer N., Clark D.G., Folta K.M., Colquhoun T.A. 2019. Effects of light quality on vegetative cutting and in vitro propagation of coleus (Plectranthus scutellarioides). HortScience 54(5): 926-935. DOI: 10.21273/hortsci13903-19.

Daud N., Faizal A., Geelen D. 2013. Adventitious rooting of Jatropha curcas L. is stimulated by phloroglucinol and by red LED light. In Vitro Cellular and Developmental Biology - Plant 49(2): 183-190. DOI: 10.1007/s11627-012-9486-4.

Davis P.A., Burns C. 2016. Photobiology in protected horticulture. Food and Energy Security 5(4): 223238. DOI: 10.1002/fes3.97.

Ercişli S., Güleryüz M. 1999. A study of the propagation of hardwood cuttings of some rose hips. Turkish Journal of Agriculture and Forestry 23: 305-310. [in Turkish with English abstract] 
Ercisli S., Esitken A., Sahin F. 2004. Exogenous IBA and inoculation with Agrobacterium rubi stimulate adventitious root formation on hardwood stem cuttings of two rose genotypes. HortScience 39(3): 533-534. DOI: 10.21273/hortsci.39.3.533.

Ercişli S., Eşitken A., Anapalı Ö., Şahin Ü. 2005. Effects of substrate and IBA-concentration on adventitious root formation on hardwood cuttings of Rosa dumalis. Acta Horticulturae 690: 149-152. DOI: 10.17660/actahortic.2005.690.22.

Halliday K.J., Martínez-García J.F., Josse E.M. 2009. Integration of light and auxin signaling. Cold Spring Harbor Perspectives in Biology 1(6); a001586; 11 p. DOI: $10.1101 /$ cshperspect.a001586.

Hoşafçı H., Arslan N., Sarıhan E.O. 2005. Propagation of dogrose (Rosa canina L.) plants by softwoods cuttings. Acta Horticulturae 690: 139-142. DOI: 10.17660/actahortic.2005.690.20.

Kazankaya A., Yörük E., Doğan A. 2005. Effect of IBA on rooting of Rosa canina hardwood cuttings from Lake Van region, Turkey. Acta Horticulturae 690: 153-158. DOI: 10.17660/actahortic.2005.690.23.

Kozai T., Niu G., Takagaki M. 2020. Plant factory. An indoor vertical farming system for efficient quality food production, 2nd ed. Academic Press, 516 p.

Lim Y.J., Eom S.H. 2013. Effects of different light types on root formation of Ocimum basilicum L. cuttings. Scientia Horticulturae 164: 552-555. DOI: 10.1016/j.scienta.2013.09.057.

Maas F.M., Bakx E.J. 1995. Effects of light on growth and flowering of Rosa hybrids 'Mercedes'. Journal of the American Society for Horticultural Science 120(4): 571-576. DOI: 10.21273/jashs.120.4.571.

Matysiak B., Markowski J., Mieszakowska-Frąc M., Piecko J. 2019. Evaluation of the utility value and health promoting of selected rose genotypes (Rosa spp.). I Sympozjum Różane, 14-16 June 2019, Polska Akademia Nauk, Ogród Botaniczny - Centrum Zachowania Różnorodności Biologicznej w Powsinie, pp. 26-27.

Miler N., Kulus D., Woźny A., Rymarz D., Hajzer D., Wierzbowski K. et al. 2019. Application of wide-spectrum light-emitting diodes in micropropagation of popular ornamental plant species: a study on plant quality and cost reduction. In Vitro Cellular and Developmental Biology 55: 99-108. DOI: 10.1007/s11627-018-9939-5. Milewski J.C. 1974. Hybrydyzacja róż owocodajnych w celu uzyskania wysokiej zawartości witaminy $\mathrm{C}$ w owocniach. Prace Instytutu Badawczego Leśnictwa 474: 127-172. [in Polish]

Nhut D.T., Takamura T., Watanabe H., Okamoto K., Tanaka M. 2003. Responses of strawberry plantlets cultured in vitro under superbright red and blue lightemitting diodes (LEDs). Plant Cell, Tissue and Organ Culture 73(1): 43-52 DOI: 10.1023/a:1022638508007.

Pacurar D.I., Perrone I., Bellini C. 2014. Auxin is a central player in the hormone cross-talks that control adventitious rooting. Physiologia Plantarum 151(1): 83-96. DOI: 10.1111/ppl.12171.

Poudel P.R., Kataoka I., Mochioka R. 2008. Effect of red- and blue-light-emitting diodes on growth and morphogenesis of grapes. Plant Cell, Tissue and Organ Culture 92(2): 147-153. DOI: 10.1007/s11240-007-9317-1.

Schneider A., Godin C., Boudon F., Demotes-Mainard S., Sakr S., Bertheloot J. 2019. Light regulation of axillary bud outgrowth along plant axes: An overview of the roles of sugars and hormones. Frontiers in Plant Science 10; 1296; 17 p. DOI: 10.3389/fpls.2019.01296.

Schroeter-Zakrzewska A., Kleiber T. 2014. The effect of light colour and type of lamps on rooting and nutrient status in cuttings of Michaelmas daisy. Bulgarian Journal of Agricultural Science 20: 1426-1434.

Wojtania A., Matysiak B. 2018. In vitro propagation of Rosa 'Konstancin' ( $R$. rugosa $\times R$. beggeriana), a plant with high nutritional and pro-health value. Folia Horticulturae 30(2): 259-267. DOI: 10.2478/fhort-2018-0022.

Wu H.C., Lin C.C. 2012. Red light-emitting diode light irradiation improves root and leaf formation in difficult-to-propagate Protea cynaroides L. plantlets in vitro. HortScience 47: 1490-1494. DOI: 10.21273/hortsci.47.10.1490.

van Dalfsen P., Slingerland L. 2012. Stekken onder LEDverlichting 2. Wageningen University and Research, the Netherlands, 29 p. [in Dutch] 